\title{
EPIDERMAL GROWTH FACTOR (EGF) AS A POTENTIAL TARGETING AGENT FOR DELIVERY OF BORON TO MALIGNANT GLIOMAS
}

Jacek Capala ${ }^{1 *}$, Rolf F. Barth ${ }^{1}$, Dianne M. Adams ${ }^{1}$, Michael Q. Bailey ${ }^{2}$, Albert H. Soloway ${ }^{3}$ and Jörgen Carlsson ${ }^{4}$

Departments of Pathology ${ }^{1}$ and Veterinary Clinical Science ${ }^{2}$ and ${ }^{3}$ College of Pharmacy,

RECEIVED

The Ohio State University, Columbus, Ohio 43210 , U.S.A. and

MAR 251996

${ }^{4}$ Department of Radiation Sciences, Uppsala University, Uppsala, Sweden.

\section{INTRODUCTION}

The majority of high grade gliomas express an amplified epidermal growth factor receptor (EGFR) gene, and this often is associated with an increase in cell surface receptor expression ${ }^{1,2}$. The rapid internalization and degradation of EGF-EGFR complexes, as well as their high affinity make EGF a potential targeting agent for delivery of ${ }^{10} \mathrm{~B}$ to tumor cells with an amplified number of EGFR. Human glioma cells can expresses as many as $10^{5}-10^{6}$ EGF receptors per cell, and if these could be saturated with boronated EGF, then $>10^{8}$ boron atoms would be delivered per cell. Since EGF has a comparatively low molecular weight $(-6 \mathrm{kD})$, this has allowed us to construct relatively small bioconjugates containing - 900 boron atoms per EGF molecule ${ }^{3}$, which also had high affinity for EGFR on tumor cells. In the present study, the feasibility of using EGF receptors as a potential target for therapy of gliomas was investigated by in vivo scintigraphic studies using ${ }^{131} \mathrm{I}$ - or ${ }^{99 \mathrm{~m}} \mathrm{Tc}$-labeled EGF in a rat brain tumor model. Our results indicate that intratumorally delivered boron- EGF conjugates might be useful for targeting EGFR on glioma cells if the boron containing moiety of the conjugates persisted intracellularly. Further studies are required, however, to determine if this approach can be used for BNCT of the rat glioma.

\section{MATERIALS AND METHODS}

\subsection{Cells}

Rat glioma $\mathrm{C} 6_{\mathrm{EGFR}}$ cells were produced by transfecting the $\mathrm{C} 6$ rat glioma with the gene encoding for EGFR, and as determined by a radioligand binding assay and Scatchard analysis, expressed $3 \times 10^{6}$ receptors per cell ${ }^{4}$.

\subsection{Preparation of boronated EGF conjugates}

"Starburst" dendrimers, which are composed of repetitive polyamido amino groups arranged in a starburst pattern, were boronated with $\mathrm{Na}\left(\mathrm{CH}_{3}\right)_{3} \mathrm{NB}_{10} \mathrm{H}_{8} \mathrm{NCO}$ as previously described ${ }^{5}$. EGF was first modified with $\mathrm{m}$-maleimidobenzoyl-N-hydroxysulfosuccinimide ester (sMBS) and then linked to boronated starburst dendrimers, derivatized with $\mathrm{N}$-succinimidyl 3-(2-pyridyldithio) propionate (SPDP). The reaction mixture was passed through a Sephadex G-50 column and eluted with $0.1 \mathrm{M}$ TRIS, $0.2 \mathrm{M} \mathrm{NaCl}$ buffer $(\mathrm{pH}=8.5)$. One ml fractions were collected and protein concentrations were determined spectrophotometrically by measuring absorbance at $280 \mathrm{~nm}$ and boron was quantified by means of direct current plasma atomic emission spectroscopy (DCP-

* Present address: Brookhaven National Laborotory, Upton, NY 11973 


\section{DISCLAIMER}

Portions of this document may be illegible in electronic image products. Images are produced from the best available original document. 
AES). Fractions containing peak concentrations of both protein and boron were pooled and used in the studies described in the following sections. The final concentration of EGF was precisely determined using Water's pico-TAG system ${ }^{6.7}$ for amino acid analysis of the boronated EGF (BEGF).

\subsection{Receptor binding assay}

Reactivity of boronated and native EGF with $\mathrm{C}_{\mathrm{EGFR}}$ cells was studied by means of a competitive binding assay. $\mathrm{C6}_{\mathrm{EGFR}}$ cells $\left(-5 \times 10^{6}\right.$ cells/well) were seeded into 24 well plates (Corning, Corning, NY) and incubated with medium containing $0.185 \mathrm{nM}$ of ${ }^{125}$ I-EGF and varying concentrations of native $(0-83 \mathrm{nM})$ or boronated $(0-410 \mathrm{nM})$ EGF at $4{ }^{\circ} \mathrm{C}$ for $90 \mathrm{~min}$. The cells then were washed three times with cold phosphate buffered saline (PBS, $\mathrm{pH}=7.2$ ) and cell associated activity was determined by gamma scintillation counting. Affinity constants $\left(\mathrm{K}_{\mathrm{A}}\right)$ were calculated using a four-parameter logistic equation for fitting the competition curve to the experimental displacement data ${ }^{8}$.

\subsection{Radiolabeling of EGF}

EGF was radioiodinated by means of the chloramine-T method. EGF was labeled with ${ }^{99 \mathrm{~m}} \mathrm{Tc}$ by first treating it with 2 -iminothiolane $(50 \mathrm{x}$ molar excess) in order to introduce a thiol group into the aminoterminal and then reacting it, in reducing buffer, with $10 \mathrm{mCi}$ of ${ }^{99 \mathrm{~m}} \mathrm{Tc}$ sodium pertechnate (Mallinckrodt Medical Inc., St. Louis, MO) ${ }^{9}$.

\subsection{In vivo scintigraphic studies.}

$\mathrm{C6}_{\mathrm{EGFR}}$ cells $\left(10^{5}\right)$ were implanted stereotactically into the right caudate nuclei of Fischer rats as previously described ${ }^{4}$. The distribution of radioactivity following intracerebral (i.c.) or intratumoral injection of ${ }^{131} \mathrm{I}$ - or ${ }^{99 m}$ TC-EGF in normal or tumor bearing animals was determined by means of external scintigraphy using a Technicare 438 gamma camera.

\section{RESULTS AND DISCUSSION}

Boronated "starburst" dendrimers were conjugated to EGF using SMBS and SPDP as chemical linkers. Based on protein and boron determinations, it was calculated that the bioconjugates contained - 900 atoms of boron per EGF molecule. Assuming that $10^{5}-10^{6}$ EGFR on each tumor cell could be saturated with boronated EGF, then $>10^{8}$ boron atoms would be delivered to tumor cell. As determined by competitive binding assays, $83 \mathrm{nM}$ of native EGF produced a $98 \%$ decrease in ${ }^{125}$ I-EGF binding and $410 \mathrm{nM}$ of boronated EGF produced a $96 \%$ decrease in ${ }^{125} \mathrm{I}$ EGF binding (Fig. 1). The calculated $\mathrm{K}_{\mathrm{A}}$ for native EGF was $9.1( \pm 3.3) \times 10^{8} \mathrm{M}^{-1}$, compared to $8.55( \pm 0.9) \times 10^{7} \mathrm{M}^{-1}$ for B-EGF, indicating that linkage of the boronated "starburst" dendrimer to EGF produced a - 10-fold decrease in the $K_{A}$ of the conjugate. Nevertheless, the $\mathrm{K}_{\mathrm{A}}$ of the $\mathrm{B}-\mathrm{EGF}$ compared favorably to the $\mathrm{K}_{\mathrm{A}}$ of MoAbs that have been used for in vivo targeting of radionuclides and toxins ${ }^{10}$.

External scintigraphy, following injection of ${ }^{131} \mathrm{I}$-EGF, showed that ${ }^{131} \mathrm{I}$ radioactivity disappeared more rapidly from the brain region of tumor bearing animals compared to non-tumor bearing ones (Fig. 2). This may have been due to dehalogenation of EGF following its internalization and 
degradation by tumor cells. In contrast, following injection of ${ }^{99 \mathrm{~m}} \mathrm{Tc}-\mathrm{EGF},{ }^{99 \mathrm{~m}} \mathrm{Tc}$ radioactivity persisted for longer periods of time in the brain region of $\mathrm{C}_{\mathrm{EGFR}}$ bearing rats compared to non tumor bearing animals (Fig. 3).

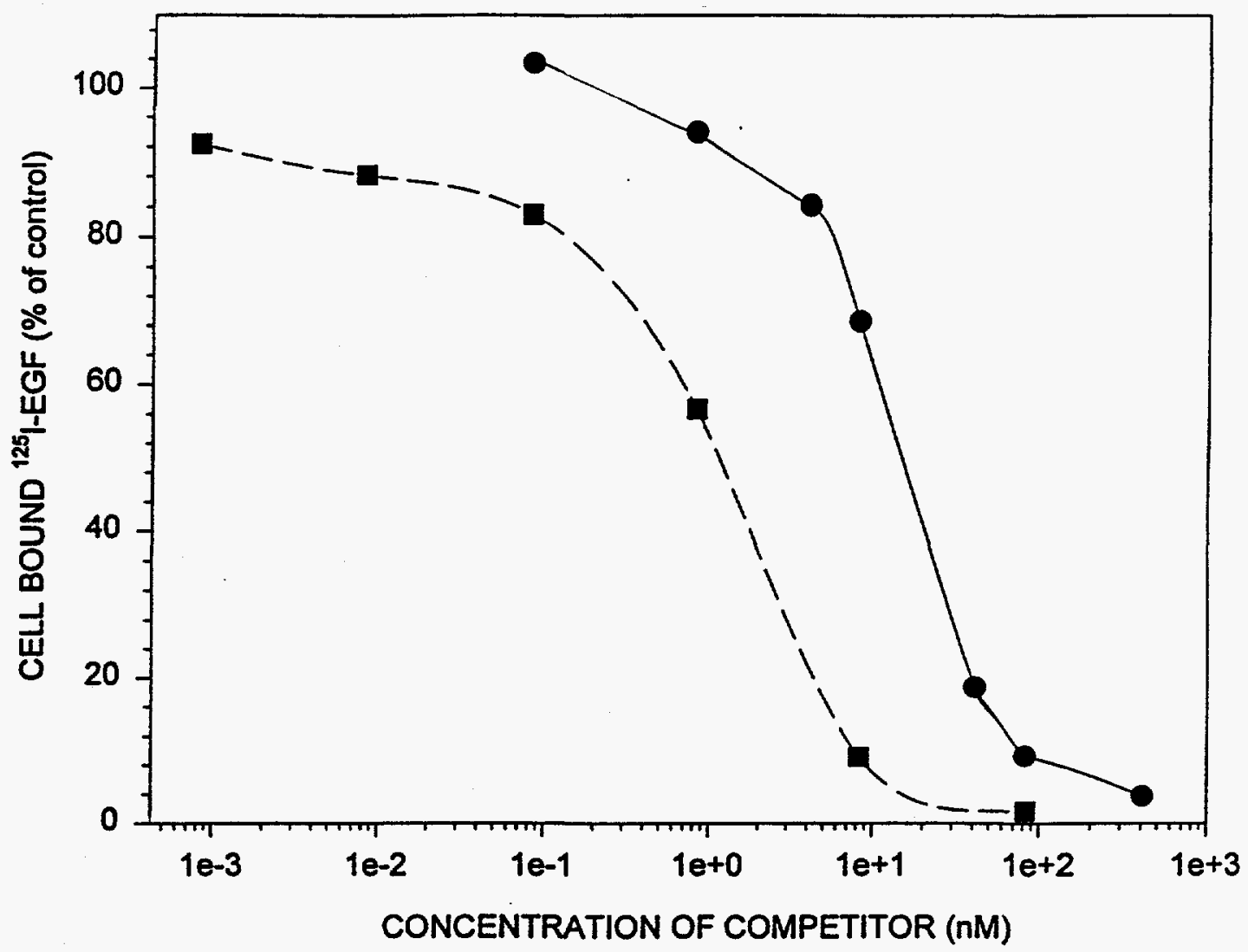

Figure 1. Inhibition of ${ }^{125} \mathrm{I}$-EGF binding obtained when increasing concentrations of native ( $\square$ ) or boronated (๑) EGF were used as competitors. $5 \times 10^{5}$ cells/well were incubated at $4^{\circ} \mathrm{C}$ for 90 $\mathrm{min}$ in medium containing $0.185 \mathrm{nM}$ of ${ }^{125}$ I-EGF and various concentrations of native $(0-83 \mathrm{nM})$ or boronated $(0-410 \mathrm{nM})$ EGF. Then, the cells were washed in cold PBS and the cell associated activity was determined.

This suggested that either ${ }^{99 \mathrm{~m}} \mathrm{Tc}$-EGF was not degraded or that ${ }^{99 \mathrm{~m}} \mathrm{Tc}$ radioactivity remained in tumor cells after degradation of ${ }^{99 \mathrm{~m}} \mathrm{Tc}$-EGF. Intratumorally injected EGF most likely had been catabolized by the tumor cells, as suggested by faster disappearance of ${ }^{131} \mathrm{I}$ from the brain, lower levels of radioactivity in the liver and more rapid accumulation of iodine in the thyroid. Following the injection of ${ }^{99 \mathrm{~m}} \mathrm{Tc}$ labeled EGF, - $60 \%$ of ${ }^{99 \mathrm{~m}} \mathrm{Tc}$ remained in the region of brain tumor for up to 12 hours, while in non-tumor bearing animals only $-20 \%$ of the injected radioactivity was detected in the brain region at six hours (Fig. 4). This is in agreement with results of our in vitro experiments with ${ }^{131} \mathrm{I}$ - or ${ }^{99 \mathrm{~m}} \mathrm{Tc}$-EGF, in which ${ }^{131} \mathrm{I}$ radioactivity was rapidly released from the cells, while $-60 \%$ of ${ }^{99 m} \mathrm{Tc}$ radioactivity remained in the cells up to six hours (data not shown). Since intratumorally injected EGF may be catabolized by the tumor cells, it is essential that the boron containing molecules be designed so that they remain within the cells even after EGF has been degraded. 


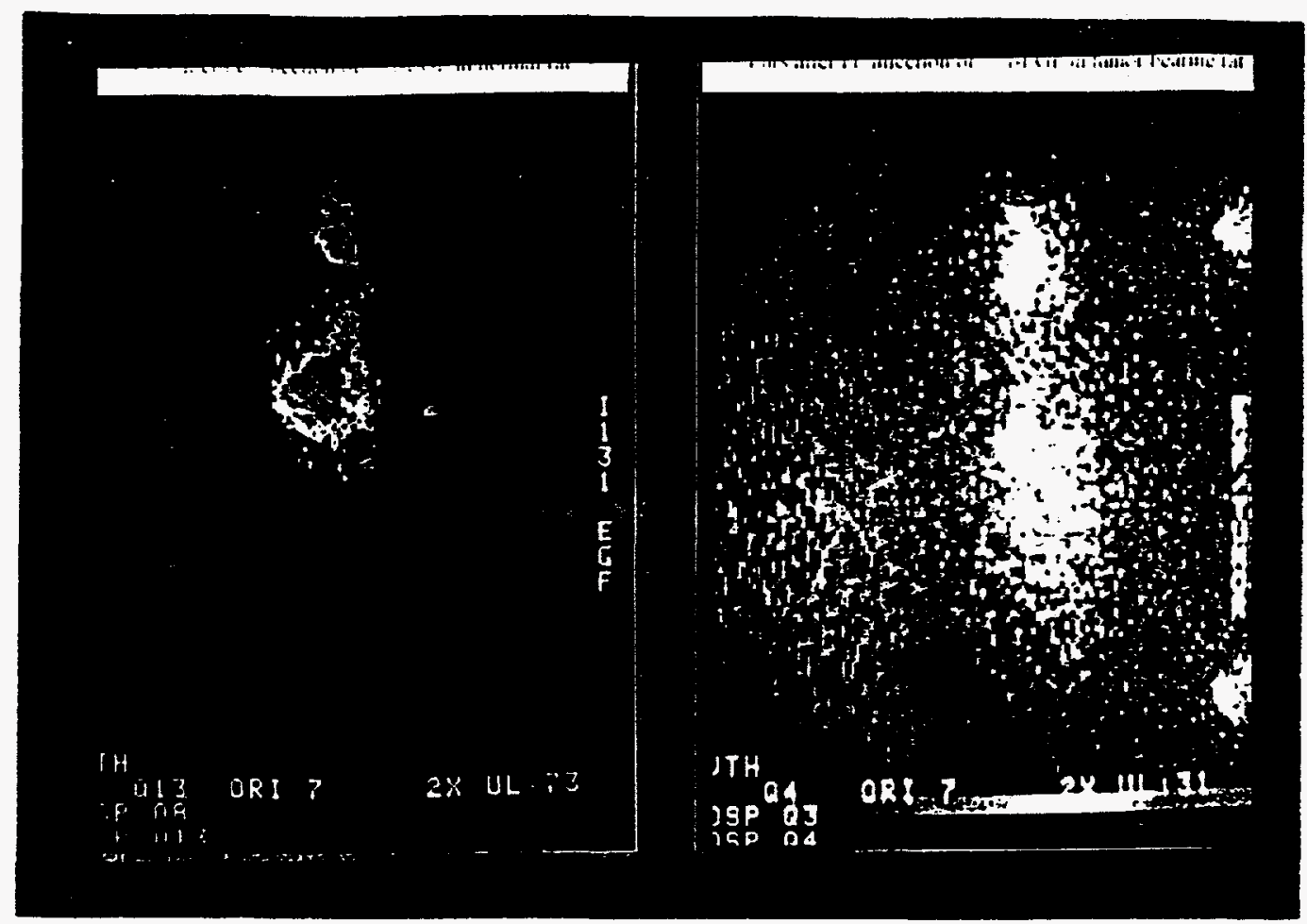

Figure 2. Scans of ${ }^{131}$ I distribution $24 \mathrm{hrs}$ after i.c. injection of $-5 \mu \mathrm{g}$ of ${ }^{131} \mathrm{I}$-EGF $(200 \mu \mathrm{Ci})$ in normal rats (left panel) or intratumoral injection of $\sim 1 \mu \mathrm{g}$ of ${ }^{131}$ I-EGF $(60 \mu \mathrm{Ci})$ in tumor bearing rats (right panel).

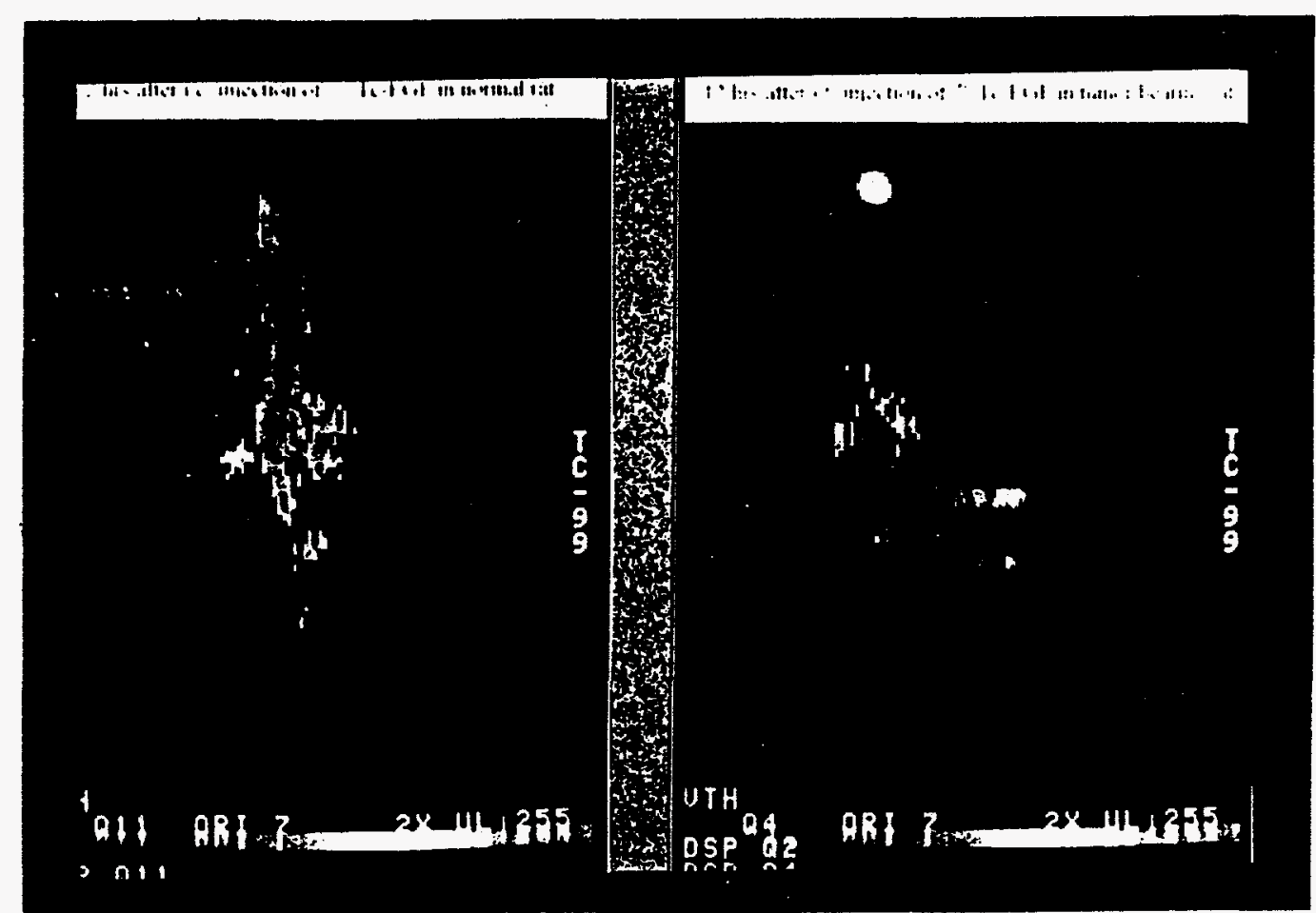

Figure 3. Scans of ${ }^{99 \mathrm{~m}} \mathrm{Tc}$ distribution $12 \mathrm{hrs}$ after i.c. injection of $-2.3 \mu \mathrm{g}$ of ${ }^{99 \mathrm{~m}} \mathrm{Tc}-\mathrm{EGF}$ (43 $\mu \mathrm{Ci}$ ) in normal rats (left panel) or intratumoral injection of $-1.7 \mu \mathrm{g}$ of ${ }^{99 \mathrm{~m}} \mathrm{Tc}-\mathrm{EGF}(34 \mu \mathrm{Ci})$ in tumor bearing rats (right panel). 


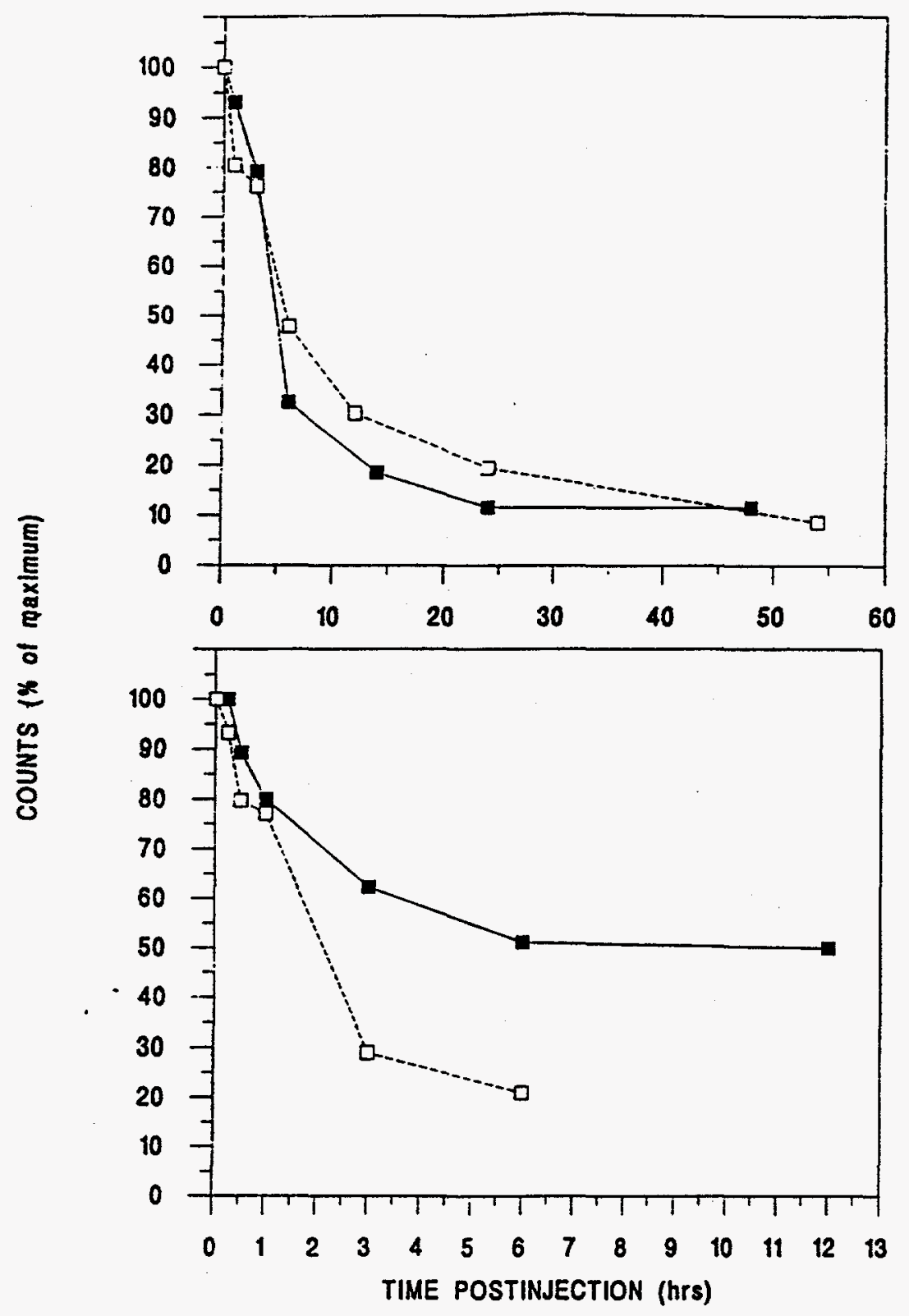

Figure 4. Quantitative evaluation of ${ }^{131} \mathrm{I}$ (upper panel) or ${ }^{99 \mathrm{~m}} \mathrm{Tc}$ (lower panel) radioactivity retained in the brain region of normal ( $\square$ ) or tumor bearing ( $\square$ ) rats.

In order for boronated EGF to be useful as a targeting agent for BNCT of gliomas, the following criteria must be met: 1. the conjugates must retain their high affinity for EGF receptors in vivo; 2. following either systemic or local administration, sufficient amounts must reach glioma cells dispersed within normal brain; 3 . the boron must persist intracellularly within glioma cells for a longer time than that required to clear from normal brain.

Since there may be considerable variability in the cellular expression of EGFR within any given glioma, combinations of low and high molecular weight delivery systems could be used to target different subpopulations of tumor cells. In order to determine the potential usefulness of EGF as a targeting agent for BNCT of gliomas, further in vivo studies will be carried out to define the biodistribution and pharmacokinetics of B-EGF following different routes of administration. 


\section{REFERENCES}

1. H. Modjtahedi and C. Dean, The receptor for EGF and its ligands: expression, prognostic value and target for therapy in cancer (Review), Int. J. Oncol. 4:227-296,1994.

2. S.H. Trop, E.Helseth, A. Dalen and G. Unsgaard, Epidermal growth factor receptor expression in human gliomas, Cancer Immunol. Immunother. 33:61-63,1991.

3. J. Capala, R.F. Barth, D.M. Adams, A.H. Soloway and J. Carlsson. Epidermal growth factor as a potential targeting agent for delivery of ${ }^{10} \mathrm{~B}$ to malignant gliomas, in "Advances of Neutron capture Therapy" A.H. Soloway, R.F. Barth, D.E. Carpenter, eds. Plenum Press, N.Y., 1993, pp. 371-375.

4. R.A. Fenstermaker, J. Capala, A. Hujer, R.F. Barth, H.-J. Kung and D.M. Kaetzel Jr., Implantable $\mathrm{C} 6$ glioma cell lines transfected with the epidermal growth factor receptor gene, Cancer Research, 1994, submitted.

5. R.F. Barth, D.M. Adams, A.H. Soloway, F. Alam and M.V. Darby, Boronated starburst dendrimer-monoclonal antibody immunoconjugates: evaluation as a potential delivery system for neutron capture therapy. Bioconjug. Chem. 5:58-66, 1994.

6. B.A. Bidlingmeyer, S.A. Cohen and T.L. Tarvin Rapid analysis of amino acids using precolumn derivatization, J. Chromatography 336:93-104, 1984.

7. S.A. Cohen, T.L. Tarvin and B.A. Bidlingmeyer, Amino acid analysis using pre-column derivatization with phenylisothiocyanate: Matrix effects and tryptophan analysis, in: "Proteins: Structure and Function", J.J. L'Italien ed. Plenum Press, NY, 1987, pp. 207-213.

8. P.J. Munson, Heterogenous receptors and binding curve analysis in neurobiology, in: "Brain Receptor Methodologies, Part A: General Methods and Concepts. Amines and Acetylcholine", P.J. Marangos, I.C.Campbell and R.M. Cohen, eds. Academic Press, Inc., New York, NY, 1984, pp.33-48.

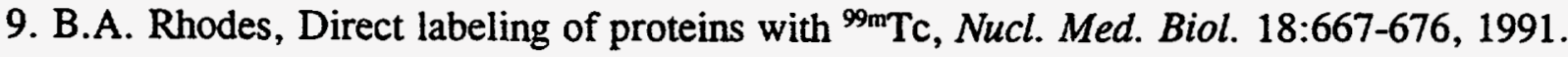

10. O.A. Oredipe, R.F. Barth, J.H. Rotaru and Z. Steplewski, Lack of effect of recombinant human interferon- $\alpha 2 b$ on expression of 17-1A antigen on human colon cancer cells, Hybridoma 11:607-615, 1992.

ACKNOWLEDGEMENTS

Th1s research was supported in part by the U.S. Department of Energy under Contract DE-ACO2-76CH00016.

\section{DISCLAIMER}

This report was prepared as an account of work sponsored by an agency of the United States Government. Neither the United States Government nor any agency thereof, nor any of their employees, makes any warranty, express or implied, or assumes any legal liability or responsibility for the accuracy, completeness, or usefulness of any information, apparatus, product, or process disclosed, or represents that its use would not infringe privately owned rights. Referprocess disclosed, or represents that its use would not infringe prive or service by trade name, trademark, manufacturer, or otherwise does not necessarily constitute or imply its endorsement, recommendation, or favoring by the United States Government or any agency thereof. The views and opinions of authors expressed herein do not necessarily state or reflect those of the United States Government or any agency thereof. 